\title{
Differentially expressed gene products in glioblastoma cells suppressed for tumorigenicity
}

\author{
Azra H Ligon ${ }^{1,2}$, Mark A Pershouse ${ }^{1}$, Samar Jasser ${ }^{1}$, Yong-Kil Hong, ${ }^{1,3}$, WK Alfred Yung ${ }^{1}$ and Peter A Steck ${ }^{1}$ \\ ${ }^{1}$ Department of Neuro-Oncology, Box 316, The University of Texas MD Anderson Cancer Center, 1515 Holcombe \\ Boulevard, Houston, Texas 77030, USA
}

\begin{abstract}
The loss of large segments or an entire copy of chromosome 10 is the most common genetic alteration in human glioblastomas. To address the biological and molecular consequences of this chromosomal alteration, we transferred a human chromosome 10 into a glioma cell clone devoid of an intact copy. The hybrid cells exhibited an altered cellular morphology, a decreased saturation density, and a suppression of both anchorage-independent growth and tumor formation in nude mice. The hybrids also expressed the recently identified candidate tumor suppressor gene $M M A C 1 / P T E N$. To further identify gene products that may be involved in glioma progression, a subtractive hybridization was performed between the human glioblastoma cells and the phenotypically suppressed hybrid cells to identify differentially expressed gene products. Sixty-one clones were identified, with nine clones being preferentially expressed in the hybrid cells. Four cDNA clones represented markers of differentiation in glial cells. Two cDNA clones shared homology with platelet derived growth factor- $\alpha$ and the insulin receptor, respectively, both genes previously implicated in glioma progression. A novel gene product that was expressed predominantly in the brain, but which did not map to chromosome 10, was also identified. This clone contained an element that was also present in three additional clones, two of which also exhibited differential expression. Consequently, the presence of a functional copy of chromosome 10 in the glioma cells results in differential expression of a number of gene products, including novel genes as well as those associated with glial cell differentiation.
\end{abstract}

Keywords: MMAC1; chromosome 10; differential gene expression; tumor suppression

\section{Introduction}

Glial tumors account for the largest percentage of primary tumors of the central nervous system. In their most malignant and prevalent form these tumors are classified as glioblastoma multiforme (GBMs) with an average patient survival of approximately 1 year. The vast majority of GBM examined by either karyotypic or molecular analyses have shown a multiplicity of chromosomal aberrations including amplification of chromosome 7, and regional deletions or monosomies of chromosomes 9p21, 10p, 10q, 11p15, 13q13, 17p13, 19, and 22 (Bigner et al, 1988; 1990; Fults et al, 1989, 1990; 1992; James et al, 1988, 1991; Rasheed et al, 1992,

Correspondence: PA Steck,

Current addresses: ${ }^{2}$ Brigham and Women's Hospital, Department of Obstetrics, Gynecology Reproductive Biology, and Department of Pathology, 75 Francis Street, Boston, Massachusetts, USA; ${ }^{3}$ Department of Neurosurgery, Catholic University Medical College, Seoul, Korea

Received 3 September 1997; revised 4 December 1997; accepted 12 January 1998
1995; Ransom et al, 1992; Ritland et al, 1995). The most common chromosomal alteration involves an apparent grade-specific loss of chromosome 10 alleles associated with high grade GBMs. Frequently, an entire copy of chromosome 10 is lost in GBM but only rarely in the histologically lower grade gliomas (James et al, 1988; Fults et al, 1990; Rasheed et al, 1992). These observations suggest that chromosome 10 may harbor one or more tumor suppressor genes whose loss of function is involved in the progression of gliomas from low to high grade. The amplification and alteration of epidermal growth factor receptor (EGF-R) on chromosome 7 has been shown to occur predominantly during the progression to GBM and to be associated with loss of chromosome 10 (Fults and Pedone, 1993; Wong et al, 1987; von Diemling et al, 1992).

To investigate the possible biological role(s) of chromosome 10 alteration in GBM, we had previously transferred a single copy of chromosome 10 into a human GBM-derived cell line, U251, and 
showed a suppression of the in vitro and in vivo tumorigenic properties of the hybrid cells compared to those of the parental cells (Pershouse et al, 1993). In addition, chromosomal fragmentation was used to map at least two tumor suppressive loci on chromosome 10, one each on the short and long arms (Steck et al, 1995). Recently, our laboratory and Parsons and co-workers have identified a candidate tumor suppressor gene (MMAC1/PTEN) at 10q23.3 that is altered in a large number of gliomas and several other human cancers (Steck et al, 1997; Li et al, 1997). MMAC1 is a dual specificity phosphatase (Myers et al, 1997) with homology to the cytoskeleton proteins tensin and auxillin, although its role in tumor suppression and signal transduction is currently unknown. An additional candidate tumor suppressor gene distal to this region, DMBT1 (10q25.3-26.1), has recently been identified and found to be deleted in malignant brain tumors (Mollenhauer et al. 1997). However, the precise biological role for DMTB1 remains to be elucidated. In this study, we have generated microcell hybrid cells that are phenotypically suppressed, express $M M A C 1$ and fortuitously lack an intact chromosome 10 in the parental cells. Furthermore, a subtractive hybridization was performed between the GBM cells and their nontumorigenic hybrid counterparts to isolate gene sequences which are differentially expressed and which may be directly or indirectly involved in glioma oncogenesis.

\section{Results}

Generation and characterization of hybrid cells containing chromosome 10

To assess the biological and molecular alterations associated with the loss of intact chromosome 10 in human gliomas, a chromosome 10 was introduced into LG11 cells using microcell-mediated transfer to generate LG11.S3 hybrid cells. The transfer of chromosome 10 into LG11 cells was documented by karyotyping of LG11.S3 cells and showing that an intact copy of chromosome 10 was present. This is in contrast to LG11 cells which lack an intact homologue of chromosome 10 (Figure 1A, B). The status of chromosome 10 in LG11 cells was also examined by chromosome painting of LG11 metaphases with chromosome 10-specific inter-alu-PCR products and allelotyping. Several shortened chromosome 10 fragments and small unidentifiable marker chromosomes, half of which contained chromosome 10 material, were observed (Figure 1C). Allelotyping of LG11 cells and fibroblasts derived from the same patient revealed loss of heterozygosity for every informative polymorphic probe examined for chromosome 10 suggesting that LG11 cells lost one copy of chromsome 10 and duplicated the remaining fragmented copy. The breakpoint on chromosome 10 was partially mapped to $10 \mathrm{q} 24-25$ by fluorescence in situ
A

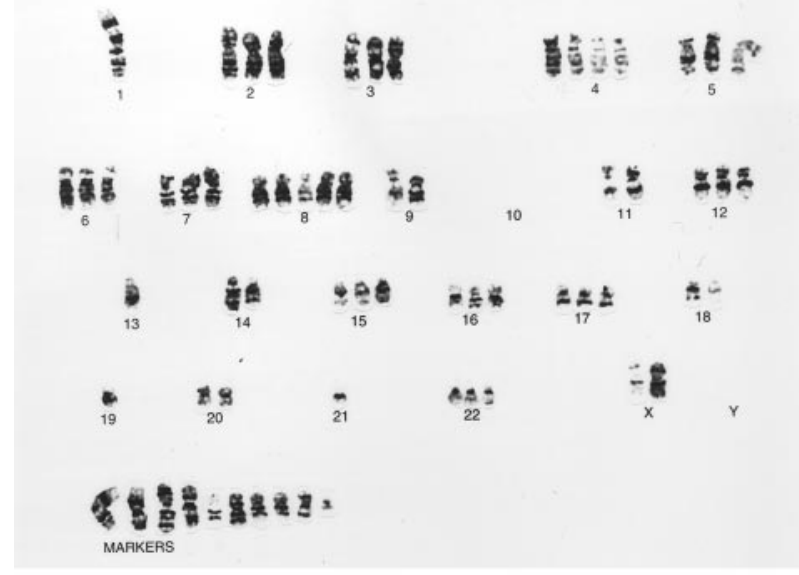

B
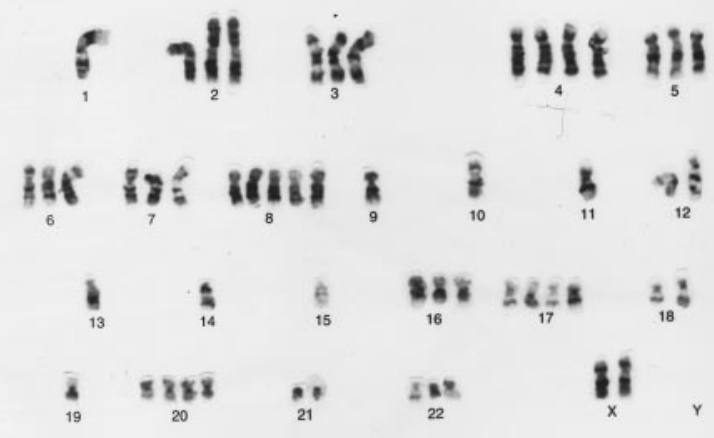

ป⿻ำ

C

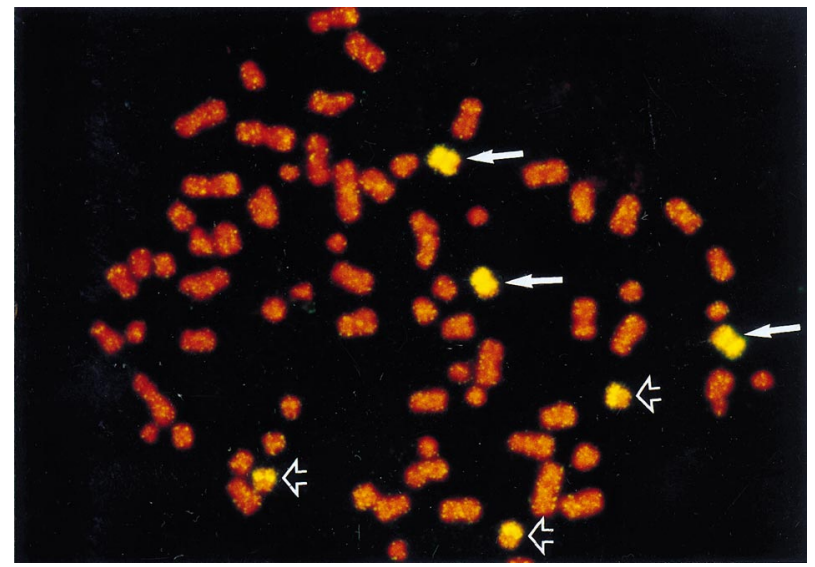

Figure 1 Representative G-banded karyotypes of LG11 cells (A) and LG11.S3 cells (B). A number of marker chromosomes were found in each karyotype. Note the presence of an intact chromosome 10 in LG11.S3 cells. (C) Result of fluorescence in situ hybridization using biotinylated human chromosome 10 specific inter-Alu probes hybridized against metaphase spreads prepared from LG11 cells, illustrating fragments of chromosome 10 in LG11 cells. The large fragment (solid arrow) contains the region from 10pter to $\sim 10 \mathrm{q} 23$, while the translocated fragment (open arrow) contains the remainder of the long arm. 
hybridization of YAC clones. This break occurred near ( $\sim 10 \mathrm{cM}$ ) but not at the MMAC1 locus, even though a homozygous deletion was shown to occur within this gene (Steck et al, 1997). Allelotyping of LG11.S3 cells also demonstrated gain of chromosome 10 polymorphic alleles identical to those of the donor cells, thereby providing molecular evidence for the presence of a new chromosome 10 in the LG11.S3 cells. Further analysis of LG11.S3 cells using polymorphic microsatellite probes for each arm of every chromosome revealed no numerical increase other than for chromosome 10 (data not shown).

The LG11.S3 cells were assayed to determine their in vitro and in vivo biological properties. The LG11 and LG11.S3 cells exhibited nearly identical growth rates with doubling times of $41 \mathrm{~h}$ and $39 \mathrm{~h}$, respectively. However, the saturation density of LG11.S3 cells was found to be significantly lower $\left(2.3 \times 10^{4}\right.$ cells $\left./ \mathrm{cm}^{2}\right)$ compared to that of LG11 cells $\left(11 \times 10^{4}\right.$ cells $/ \mathrm{cm}^{2}$; Figure 2$)$. The morphology of LG11.S3 cells appeared more 'astrocytic' (i.e. astrocytic-like processes present at low cell density, seldom observed in LG11 cells, Figure 2). LG11.S3 cells exhibited a significantly reduced ability to proliferate under anchorage-independent conditions in contrast to parental LG11 cells $(12 \pm 5$ colonies versus $967 \pm 135$ colonies per 10000 cells seeded; Figure 3).

Furthermore, the diameter of any colony that did form was significantly smaller for LG11.S3 than LG11 cells ( $325 \pm 60 \mu \mathrm{m}$ versus $75 \pm 25 \mu \mathrm{m})$ similar to that seen for U251 hybrids (Steck et al, 1995). The LG11.S3 cells failed to form tumors when injected subcutaneously into nude mice (0 tumors/12 mice; latency $>14$ months) in contrast to LG11 cells (11 tumors/11 mice; latency of 87 days for $0.5 \mathrm{~cm}^{3}$ tumors). Western blot analysis showed that the $M M A C 1$ gene product was expressed in the suppressed LG11.S3 cells but not the parental cells, indicating retention of function following the microcell-mediated chromosome transfer (Figure $4)$.

\section{Subtractive hybridization}

To identify gene products whose expression may be altered following the transfer of an intact chromosome 10, subtractive hybridization was
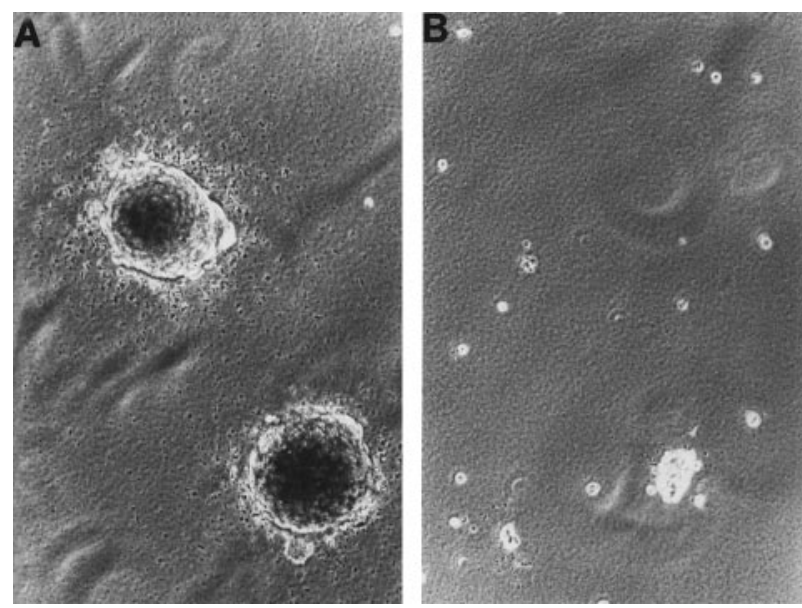

Figure 3 Photomicrographs of LG11 (A) and LG11.S3 (B) cells under anchorage-independent growth conditions. Cells were seeded at $1 \times 10^{3}$ cells per $60 \mathrm{~mm}$ culture dish. The bar represents $100 \mu \mathrm{m}$.
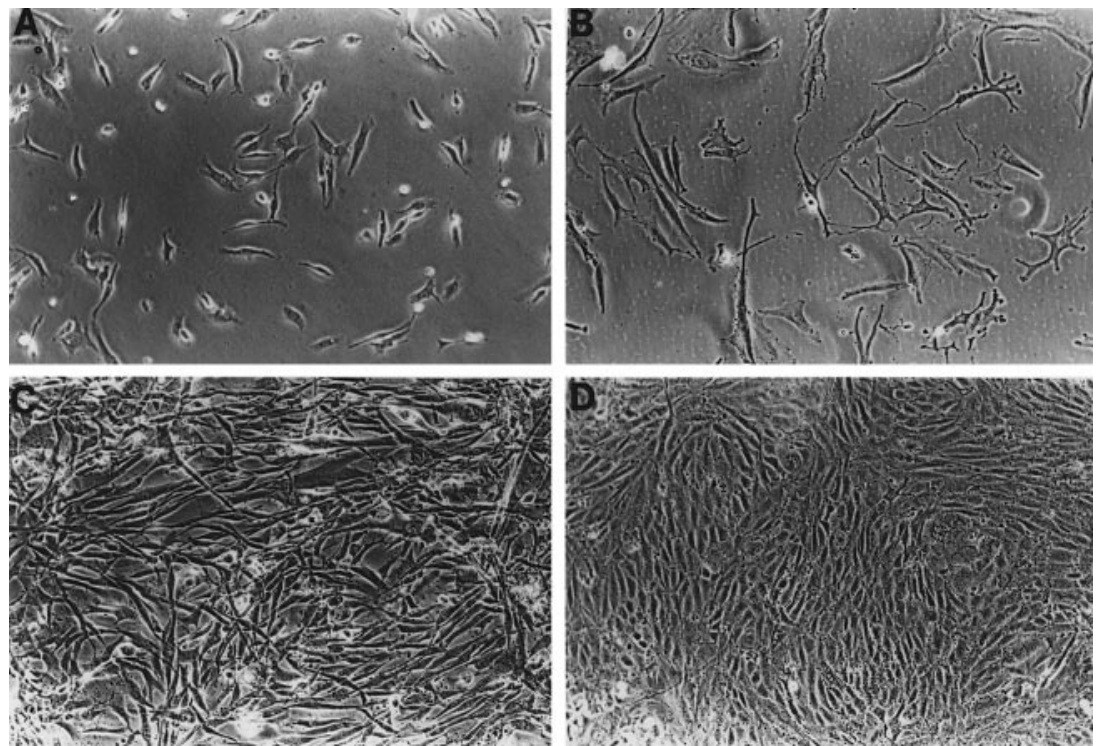

Figure 2 Photomicrographs of LG11 (A, C) and LG11.S3 (B, D) cells at sparse (A, B) and confluent (C, D) growth conditions. The LG11.S3 cells exhibit a number of processes at low cell density. 
performed using cDNA synthesized from the suppressed LG11.S3 cells and mRNA isolated from parental LG11 cells. Two rounds of subtractive hybridization were performed and the percentage of single stranded cDNA recovered between the first and second round was calculated. An increase (from $14.5-60 \%$ ) in this population of cDNA indicated enrichment of differentially expressed cDNA. The resulting un-

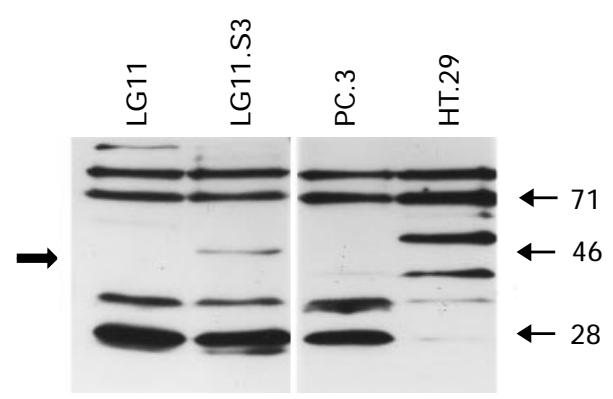

Figure 4 Western blot of cell extracts $(75 \mu \mathrm{g})$ from: LG11 and PC-3 cells, which show no MMAC1 expression due to homozygous gene deletion; LG11.S3 and HT-29 cells, which express the MMAC1 gene product is detected by an anti-MMAC1 antiserum generated against the C-terminal region of the protein. The arrow (left) depicts the MMAC1 protein and the molecular size is denoted on the right. hybridized portion of LG11.S3 cDNA was determined to be approximately $0.9 \mu \mathrm{g}$, representing $9 \%$ of the starting cDNA, suggesting that the single-stranded cDNA pool had been enriched approximately tenfold. Subsequent tertiary screening of an LG11.S3 cDNA library with radiolabeled subtracted probe resulted in the identification of 61 differentially expressed clones (average size $\sim 380 \mathrm{bp}$, range $170-870 \mathrm{bp}$ ).

Single-pass sequences of the clones were obtained and searched against expressed sequence tag (dbEST) and genomic databases using the BLAST search algorithm (Khan et al, 1992; Altschul et al, 1990). Nucleic acid homologies greater than $95 \%$ (over an average of $200 \mathrm{bp}$ ) were considered to be indicative of identical genes. Mitochondrial-encoded genes accounted for the majority $(54 \%)$ of the subtracted clones. Other known gene products included $\beta$-actin, aldolase C, ribosomal subunits L7 and L27, and apoferritin light chain. Novel gene products (23 independent clones) comprised $37 \%$ of the isolated clones. The novel sequences, with partial homology (50-95\%) over at least $50 \mathrm{bp}$, are listed in Table 1. Four novel clones failed to identify any significant matches through the BLAST search program, with six clones showing a partial homology to alu repeat elements (Table 1).

Table 1 Sequence homology of novel isolated gene products

\begin{tabular}{|c|c|c|c|c|c|c|c|c|}
\hline \multirow[b]{2}{*}{ Clone no. } & \multirow[b]{2}{*}{$\begin{array}{l}\text { Clone size } \\
\quad(b p)\end{array}$} & \multirow[b]{2}{*}{$\begin{array}{l}\text { Sequence } \\
\text { homology }^{a}\end{array}$} & \multirow[b]{2}{*}{$\begin{array}{l}\text { Homology } \\
(\%)^{b}\end{array}$} & \multirow[b]{2}{*}{$\begin{array}{c}m R N A \\
(k b)\end{array}$} & \multicolumn{4}{|c|}{ Northern expression } \\
\hline & & & & & $P$ & $S$ & $P$ & $S$ \\
\hline 3 & 350 & cyclophilin & 71 & 1 & + & ++ & +++ & +++ \\
\hline 13 & 620 & $\begin{array}{l}\text { C. elegans zinc } \\
\text { finger sdc-3 }\end{array}$ & 84 & 2 & \pm & \pm & \pm & \pm \\
\hline $\begin{array}{l}14, \\
48\end{array}$ & $\begin{array}{l}220 \\
230\end{array}$ & $\begin{array}{l}\text { oligodendrocyte } \\
\text { myelin glycoprotein }\end{array}$ & $\begin{array}{l}72, \\
86\end{array}$ & nd $^{\mathrm{d}}$ & $\begin{array}{l}- \\
-\end{array}$ & $\begin{array}{l}+ \\
-\end{array}$ & $\begin{array}{l}- \\
-\end{array}$ & - \\
\hline 17 & 330 & $\begin{array}{l}\text { IB666 (EST, infant } \\
\text { brain) }\end{array}$ & 97 & 2.6 & + & +++ & + & +++ \\
\hline 20 & 520 & $\begin{array}{l}\text { ADMLX (putative } \\
\text { adhesion molecule) }\end{array}$ & 68 & 2.5 & \pm & + & - & - \\
\hline 22 & 820 & $\begin{array}{l}\text { tal-1 (transcription } \\
\text { factor) }\end{array}$ & 70 & nd & - & - & - & - \\
\hline 33 & 170 & $\begin{array}{l}\text { Platelet-derived } \\
\text { growth factor- } \alpha\end{array}$ & 61 & 3 & \pm & + & \pm & ++ \\
\hline 35 & 370 & $\begin{array}{c}\text { human STS } \\
\text { (chromosome } \\
19 q 3.3 \text { ) }\end{array}$ & 53 & 2 & \pm & ++ & - & - \\
\hline 36 & 340 & insulin receptor & 84 & 7 & - & ++ & - & - \\
\hline 38 & 205 & human EST 01980 & 59 & nd & - & - & - & - \\
\hline 43 & 210 & $\begin{array}{c}\text { plasma membrane } \\
\text { H+ATPase }\end{array}$ & 86 & 5.5 & + & + & + & + \\
\hline 29 & 270 & Novel sequences & $a l u^{\mathrm{e}}$ & 2.5 & - & + & - & - \\
\hline 31 & 385 & $(>50 \%)$ & none & 5.5 & + & ++ & + & + \\
\hline 37 & 370 & & none & 2.2 & + & ++ & - & - \\
\hline 49 & 350 & & alu & nd & - & - & - & - \\
\hline
\end{tabular}

${ }^{\mathrm{a}}$ Homologies determined over an average of $100 \mathrm{bp} .{ }^{\mathrm{b}}$ Nucleic acid sequence homology over at least $50 \mathrm{bp}$ as determined by BLAST

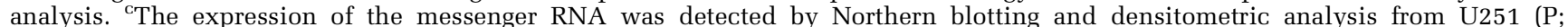
parental) and a suppressed clone (S; suppressed) and LG11 (P) and LG11.S3 (S). Quantitation of the mRNA levels was:- not detected; \pm : barely detectable; +: detectable; ++: medium abundance; and +++: highly expressed, compared to GAPDH. ${ }^{\mathrm{d}} \mathrm{nd}$ : no message detected. ${ }^{\text {e}}$ The presence of alu related sequence precluded any significant homology searches. 
The expression of all non-mitochondrial cDNA clones was assessed by Northern blot analysis using RNA isolated from LG11, LG11.S3 and U251 tumorigenic glioma cells and its chromosome 10 containing suppressed counterparts (Pershouse et al, 1993). The use of two glioma model systems (each with parental tumorigenic cells and suppressed hybrids containing an inserted chromosome 10) allows for the identification of gene products whose expression is consistently associated with the suppressed phenotypes seen in hybrid cells. The majority of the clones showed a twofold or less difference in expression levels between the parental and suppressed cells and were not analyzed further. Nine clones showed consistently increased expression in the hybrid cells compared with parental cells for at least one of the two hybrid model systems. The expression of clones 14, 20, 29, 35 and 38 was increased in the hybrid cells of the U251 system, however no message was detected in either the parental or hybrid cells of the LG11 model system (Table 1). For these clones (which shared homologies with oligodendrocyte myelin glycoprotein, ADMLX transcription factor, a novel fragment containing part of an alu repeat, a chromosome 19q3.3 EST and the insulin receptor, respectively) a significant increase $(<$ threefold) in mRNA levels was observed in the suppressed hybrid cells of the U251 system. In contrast, clone 54 (100\% homology to the apoferritin light chain gene) showed an approximately threefold increase in expression in the suppressed cells of the LG11 system, with only negligible increases seen in the U251 system.

Three clones in particular showed significant expression changes in both the U251 and LG11 model systems. Clone 43 , one of six mitochondrial clones assessed, shared $100 \%$ homology with the mitochondrial tRNA (Phe, Val, Leu) gene product, and showed a 2-3-fold increased expression in the chromosome 10-containing hybrid cells from both systems (Figure 5). Clone 33, which exhibited about $70 \%$ homology with PDGF- $\alpha$ chain, showed a twofold increase for both suppressed cell types compared to parental cells. However, the greatest differential expression was observed with clone 17, for which Northern analysis identified a $2.6 \mathrm{~kb}$ message consistently increased in the respective hybrids relative to parental cells in both model systems (4-5-fold higher than parental U251 cells and 4-10-fold higher than parental LG11 cells) (Figure 5). Sequencing of clone 17 revealed high homology exclusively to an anonymous expressed sequence tag (EST), IB666, previously isolated from an infant brain cDNA library.

\section{RIG-like gene products}

The expression pattern and additional characterization of clone 17, subsequently named RIG (regulated in gliomas), have recently been reported (Ligon et
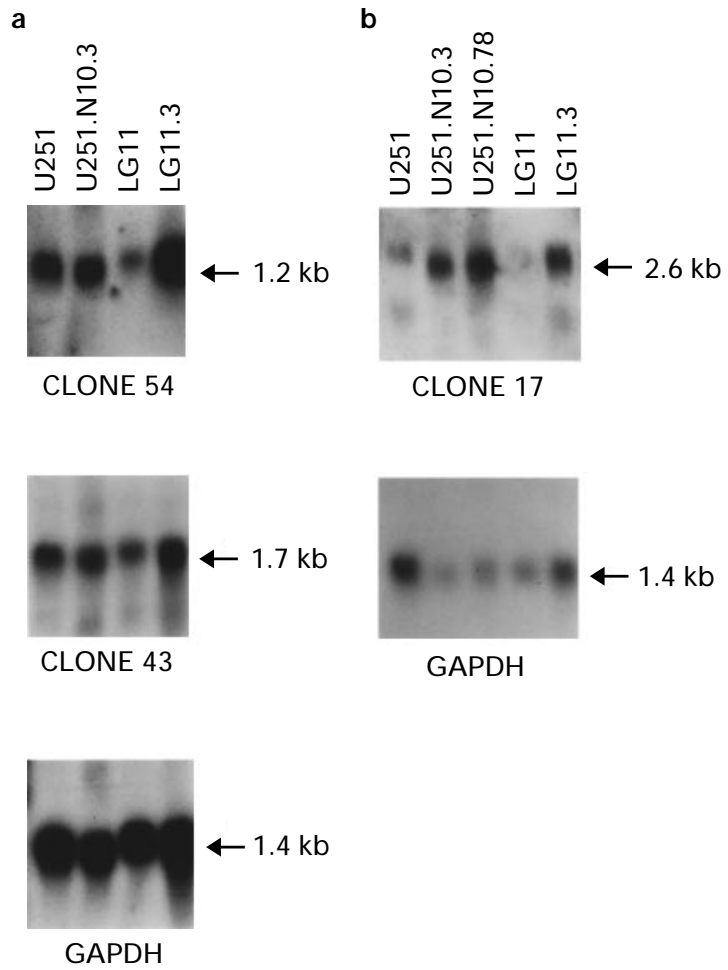

Figure 5 Northern blot analysis of differentially expressed clones using mRNA $(10 \mu \mathrm{g})$ isolated from LG11, U251, U251.N10.3, U251.N10.6 and LG11.S3 cells. Expression levels and size of clones 43 (a), 54 (b) and 17 (c) are indicated. Expression of each clone was compared with GAPDH hybridized to the same filter and quantitated by densitometric analysis. Quantitations represent an average determined from at least three independent Northern blots.

al, 1997). RIG was observed to be expressed mainly in the brain and at significantly lower levels, or not at all, in a number of GBM cell lines and primary tumors compared to normal or low grade astrocytomas. During the cloning of $R I G$, seven additional clones, representing three independent gene products, were also isolated from fetal and adult brain expression libraries. All three gene products shared a similar $\sim 150 \mathrm{bp}$ sequence, but only $R I G$ was completely identical to clone 17. A homologous region (small overlap was 208-260 bp of EST IB666) was found in the $3^{\prime}$ untranslated region of all messages, but the orientation differed between RIG and the remainder of the clones. Three clones, 7-1, 14-1 and 5-6, were partially characterized. Clones 14-1 and 7-1, like RIG, were differentially expressed in GBM cells and their nontumorigenic hybrid counterparts. The expression and size of $R I G$ and 7-1 were almost identical as determined by Northern analysis, even if the region of homology between the transcripts was first removed from probes by digestion with restriction enzymes (Figure 6). Clone 14-1 exhibited a larger $\left(M_{r}\right.$ $3.2 \mathrm{~kb}$ ) message which was also differentially expressed, while clone 5-6 showed constant expression in all cells assessed by Northern blotting 
(Table 2). The predicted protein products of the clones are presented in Table 2 and Figure 7 . BLAST searches of Genbank revealed homologies between the ESTs previously identified for RIG (Ligon et al, 1997), while searches for TIGR databases revealed several homologies at both the nucleotide and protein levels (Table 2). However, no significant homologies or recognizable motifs were noted among the various proteins.

\section{Discussion}

This study was undertaken to identify candidate genes which may be involved in, or serve as

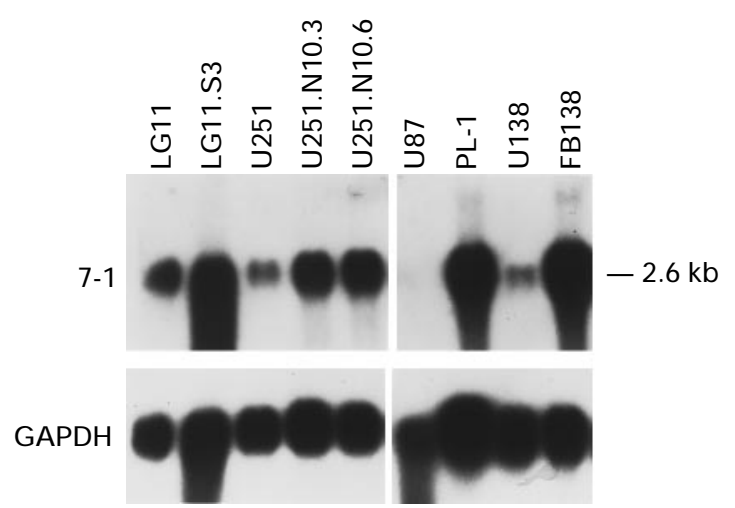

Figure 6 Northern analysis of differentially expressed clones using mRNA isolated from LG11, LG11.S3, U251, U251.N10.3, U251.N10.6, U87, PL-1, U138 and FB138 cells probed with radiolabeled cDNA 7-1 minus any sequence that is homologous with RIG (upper panel); GAPDH (lower panel). U87 and U138 are high grade gliomas, while PL-1 is a low grade glioma with intact chromosome 10s. The differential expression and message size of clone 7-1 $\left(\mathrm{M}_{\mathrm{r}} \sim 2.6 \mathrm{~kb}\right)$ were similar to the levels of expression observed for RIG for the cells examined. Densitometric quantitation for the ratio of 7-1 to GAPDH for the various cells (left to right) are $0.2,1.4,0.3,1.3,1.2,0,1.3,0.1$ and 1.8 respectively. The GAPDH probed blots were exposed to film for $5 \mathrm{~h}$, while the blot probed with 7-1 was exposed $19 \mathrm{~h}$. markers of glioma oncogenesis, and to possibly aid in elucidating the mechanism(s) of phenotypic suppression induced by the presence of a functional chromosome 10. A critical step in this study was the identification of a GBM cell line which lacked an intact chromosome 10, suggesting a potential loss of function, possibly involving a tumor suppressor gene. In fact, LG11 cells are nullisomic at the MMAC1 locus (Steck et al, 1997), while the suppressed LG11.3 cells expressed MMAC1. Similarly, U251 cells lost an entire copy of chromosome 10 and the remaining MMAC1 allele was mutated, while the suppressed hybrids expressed a wild-type MMAC1 (Pershouse et al, 1993; Steck et al, 1997). An initial step of this study involved the generation and characterization of hybrid cells containing a transferred chromosome 10. Suppression of the in vitro and in vivo tumorigenic phenotype of the parental, tumorigenic cells was demonstrated in the hybrid cells. The LG11.S3 hybrid cells also showed both a distinctive, differentiated morphology at low cell densities as well as an enhanced response to density-dependent inhibition of growth. However, the exponential growth rate was similar to that of

$$
\begin{aligned}
& \begin{array}{cccccc} 
& 10 & 20 & 30 & 40 & 50 \\
& 1 & 1 & 1 & 1 & 1 \\
14-1 & 1 & \text { MCLNYEGFODYRVIKVVVGEGEEDHCLTNIYSKNVRPKVKRVQEGDFR } &
\end{array} \\
& \text { RIG I MPFFSSCLCPSHYSGPSLPSSTSSSLPTGPENQLGFVLLOAMVHHANSSC }
\end{aligned}
$$

\begin{tabular}{|c|c|c|c|c|c|c|}
\hline Clone & $\begin{array}{l}\text { Clone size }{ }^{a} \\
\quad \text { (bp) }\end{array}$ & $\begin{array}{c}\operatorname{mRNA} \\
(\mathrm{kb})^{b}\end{array}$ & $\begin{array}{c}\text { Predicted protein } \\
\text { (kD/P.I.) }\end{array}$ & $\begin{array}{l}\text { Chromosomal } \\
\text { location }^{c}\end{array}$ & $\begin{array}{l}\text { Differential } \\
\text { expression }^{d}\end{array}$ & $\begin{array}{c}\text { Homologous } \\
\text { ESTs }^{e}\end{array}$ \\
\hline $8-1$ & 2569 & 2.6 & $13 / 9.1$ & 11p15 & + & $R I G$ \\
\hline $7-1$ & 2453 & 2.6 & $19.2 / 6.5$ & 11 & + & $\begin{array}{c}\text { N36746, } \\
\text { C01001, } \\
\text { THC166540 } \\
\text { THC196369 }\end{array}$ \\
\hline $14-1$ & 1989 & 3.2 & $9.8 / 6.1$ & 12 & + & $\begin{array}{c}\text { C14023, } \\
\text { THC198680 }\end{array}$ \\
\hline $5-6$ & 1599 & $\begin{array}{l}2.5,1.4 \\
0.8\end{array}$ & $13.2 / 9.2$ & $?$ & - & $\begin{array}{l}\text { N36746, } \\
\text { C01001, } \\
\text { N26110 }\end{array}$ \\
\hline
\end{tabular}

Figure 7 Predicted polypeptide sequences of RIG and RIG-like clones (7-1, 14-1 and 5.6). Similar peptide sequences were identified in searches for TIGR database.

Table 2 Characteristics of RIG-related clones

\footnotetext{
${ }^{a}$ Sequence determined from an individual clone (5-6) or from overlapping clones (7-1, 14-1). ${ }^{\mathrm{b}}$ Relative migration of mRNA determined by Northern blotting. ${ }^{\mathrm{c} C h r o m o s o m a l ~ l o c a t i o n ~ d e t e r m i n e d ~ b y ~ c h r o m o s o m a l ~ m a p p i n g ~ p a n e l . ~ R I G ~ w a s ~ f u r t h e r ~ l o c a l i z e d ~ b y ~}$ fluorescence in situ hybridization (Ligon et al., 1997). The chromosomal location of 5-6 could not be determined because of similarly sized mouse or hamster genes. ${ }^{\mathrm{d} D i f f e r e n t i a l ~ e x p r e s s i o n ~ i n ~ p a r e n t a l ~ G B M ~ c e l l s ~ L G 11 ~ a n d ~ U 251 ~ a n d ~ h y b r i d ~ c e l l s . ~}{ }^{e}$ ESTs from TIGR database.
} 
the tumorigenic LG11 cells. This would suggest that a functional chromosome 10 suppressor gene may be involved in determining the differentiation status or oncogenic progression of the cells rather than be associated with a proliferation-related gene product (e.g. p53 or p16).

This suggestion is also supported by the identification of gene products, through subtractive hybridization, related to differentiation of glial cells. These included oligodendrocyte myelin glycoprotein (OMGP, identified as two independent clones) and apoferritin, both of which were expressed by differentiated oligodendrocytes but not their precursors (Connor et al, 1994; Williams and Deber, 1993). The lack of expression of these markers in LG11 cells, but their observed presence in U251 cells may reflect cells at different stages of differentiation, as U251 cells express the differentiation marker glial fibrillary acidic protein but LG11 cells do not. Alternatively, the expression of these gene products may reflect the cell lineage, as certain precursor glial cells have the capacity to differentiate into astrocytes or oligodendrocytes (Raff et al, 1983).

The clone with the most profound changes in expression between the parental cells and their suppressed hybrids was clone 17. The full length structure and characterization of this gene, RIG, were recently described (Ligon et al, 1997). The expression of RIG was significantly downregulated in GBM cells which apparently suffered genetic alterations of chromosome 10. However, the induced expression of RIG in GBM cells appeared to have no detectable biological phenotypic changes (unpublished observation). The identification of several related, and differentially expressed, gene products raises several possibilities. First, while the roles of these gene products are currently undetermined, the demonstration of a consistent downregulation in tumor cells may allow these genes to serve as markers of either glial tumorigenicity, status of MMAC1 function or differentiation. Alternatively, as several independent clones appear to exhibit similar differential expression, it is also possible that their coordinate expression is required to affect some common biological function or activate a particular pathway. Furthermore, certain biological or biochemical changes in cells may go undetected by our subtraction analysis. This is exemplified by the reported increase in expression of the anti-angiogenic protein, thrombospondin, in nontumorigenic hybrid cells of the U251 and LG11 system (Hsu et al, 1996); despite the known differential expression, thrombospondin was not identified in this current analysis.

However, several other interesting sequences were identified by the subtractive hybridization, including PDGF- $\alpha$ and the insulin receptor. PDGF- $\alpha$ has been shown to be expressed by glioma cells and involve an autocrine growth loop (Nister et al,
1988). The increased PDGF- $\alpha$ expression observed in adult brain, may be related to the maintenance of glial progenitor cells (Pringle et al, 1989), or may reflect the density of the cultured cells. The insulinlike growth factor and its receptors have also previously been shown to be required for glioma cell proliferation and survival. The expression of various other growth factors was determined for LG11 and LG11.S3 cells as well as for U251 and its suppressed hybrids to determine whether the presence of a functional chromosome 10 would influence expression. No significant changes in the expression of epidermal growth factor receptor, transforming growth factor- $\alpha$, transforming growth factor $\beta$ (1 and 2), platelet derived growth factor receptor-b, or c-met were observed (data not shown). The lack of any difference in the expression of these growth factors and their receptors is not surprising given the similar exponential growth rate observed between the parental and suppressed hybrid cells.

Subtractive hybridizations have been previously used to successfully identify genes differentially expressed between two cell populations. The technique has an advantage in that chromosomal localization of target genes is not a prerequisite. The $\mathrm{v}$-src oncogene, T cell receptor, myogenic determination gene (myoD), candidates for the Duchenne type muscular dystrophy gene, and WAF-1 have all been isolated through subtractive hybridizations (Stehelin et al, 1976; El-Deiry et al, 1993; Davis, 1986). The results from our subtractive hybridization demonstrate differential expression of several classes of gene products, some of which appear to reflect the differentiation status of the suppressed cells. Finally, our results are in agreement with previous subtractive hybridizations performed between neoplastic and non-neoplastic cells, in which mitochondrial genes as well as several novel gene products have been implicated in the process of tumorigenesis or differentiation (Vayssiere et al, 1994; Sharp et al, 1992).

\section{Materials and methods}

\section{Cell lines and microcell-mediated chromosome transfer}

The human glioma cell lines LG, PL-1, and U251 were obtained and cultured as previously described (Yung et al, 1989; Pershouse et al, 1993). The LG11 clone was obtained from a well-spaced colony of LG cells grown under anchorage-independent conditions. U87MG, PC-3 cells, which are homozygously deleted for MMAC1 (Li et al, 1997) and HT-29 cells, which express MMAC1, were obtained from ATCC.

The microcell-mediated chromosomal transfer of chromosome 10 into LG11 cells was performed according to published procedures (Stubblefield and Pershouse, 1992). Selection of LG11 cells containing a transferred human chromosome 10 
was achieved using an endogenous chromosome 10 gene, adenosine kinase, and has been described (Pang et al, 1989). Briefly, selection was accomplished in the presence of adenosine $(5 \mu \mathrm{M})$, alanosine $(10 \mu \mathrm{M})$, uracil $(500 \mu \mathrm{M})$ and EHNA $(10 \mu \mathrm{M})$. EHNA and alanosine were obtained from Burroughs Wellcome Co. (Research Triangle Park, NC) and the Drug Synthesis and Chemistry Branch, Division of Cancer Treatment, National Cancer Institute (Bethesda, MD) respectively. LG11 cells were sufficiently deficient in adenosine kinase to allow for selection of additional chromosome 10 material containing the adenosine kinase gene. Karyotypic analysis, cellular proliferation, growth in soft agarose, and tumor formation of cells in nude mice were performed as previously described (Pershouse et al, 1993). Rabbit antisera against MMAC1 were generated using the synthetic peptide SDNEPDHYRYSDFTDS corresponding to residues 370-385 of MMAC1 covalently linked to acrylamide gel. The specificity of the antisera was demonstrated by examining cells which do or do not express MMAC1 and by using an excess of the peptide (1 mg) to block binding of cellular derived MMAC1. Anti-MMAC1 was detected by anti-rabbit secondary antibody conjugated to peroxidase and visualized by ECL reagent (Amersham, Chicago, IL).

\section{mRNA isolation and $c D N A$ synthesis}

Total RNA was isolated from cultured cells by adding guanidinium isothiocyanate directly to the tissue culture flasks after decanting the growth medium (Chirgwin et al, 1979). Poly $\mathrm{A}^{+}$mRNA, when used, was isolated either by oligodeoxythymidylate chromatography of total RNA samples (Aviv and Leder, 1972) or by the Fast Track mRNA isolation method (Invitrogen Co., San Diego, CA). Reverse transcription was performed using Moloney murine leukemia virus reverse transcriptase $(20 \mathrm{U} / 1 \mu \mathrm{g}$ mRNA), with trace amounts of $\left[\alpha^{32} \mathrm{P}\right] \mathrm{dCTP}$, and a mixture of oligo- $\mathrm{d}(\mathrm{T})_{12-18}$ mers and random hexamers. The generation of the complementary second strand was accomplished using RNase $\mathrm{H}$ and $E$. coli DNA polymerase. Second-strand synthesis of subtracted cDNA was initiated by hybridizing an excess of LG11.S3 mRNA to the subtracted cDNA and completed using the methods described above.

\section{Subtractive hybridization and hydroxylapatite chromatography}

LG11 mRNA was hybridized with LG11.S3 firststrand cDNA in $0.12 \mathrm{M}$ sodium phosphate ( $\mathrm{pH} 6.8$ ), $0.1 \%$ SDS, and $5 \mathrm{mM}$ EDTA in a final volume of $150 \mu \mathrm{l}$, denatured at $100^{\circ} \mathrm{C}$ for $5 \mathrm{~min}$, and then incubated at $65^{\circ} \mathrm{C}$ for $24 \mathrm{~h}$ (Sambrook et al, 1989). Single-stranded cDNA molecules were separated from RNA and double-stranded molecules using hydroxylapatite chromatography (Bio-Rad Lab., Richmond, CA) performed at $65^{\circ} \mathrm{C}$. The single- stranded products were then subjected to a second round of subtractive hybridization at a ratio of $20: 1$ (LG11 : LG11.S3), followed by hydroxylapatite chromatography.

\section{Library construction and screening}

Double-stranded LG11.S3 cDNA was cloned into the Lambda Zap II vector (Stratagene, La Jolla, CA) and packaged using Giga-Pack Gold II packaging extract (Strategene). The unamplified titer of this library was $10^{6}$ p.f.u. $/ \mathrm{ml}$ and it was screened using duplicate plaque lifts. Prehybridization was performed for $3-18 \mathrm{~h}$ at $65^{\circ} \mathrm{C}$ in $6 \times \mathrm{SSC}, 2 \times$ Denhardt's and $100 \mu \mathrm{g} / \mathrm{ml}$ sonicated salmon sperm DNA. Hybridization of filters with radioactivity labeled probes was performed overnight in the same solution. The filters were washed in $6 \times$ SSC, $1.0 \%$ SDS for $1 \mathrm{~h}$ at $65^{\circ} \mathrm{C}$ and, if needed, in $2 \times \mathrm{SSC}$, and $0.1 \%$ SDS for $20 \mathrm{~min}$ at $65^{\circ} \mathrm{C}$. Exposure time, with intensifying screens, ranged from overnight to 5 days at $-80^{\circ} \mathrm{C}$.

Inserts from the positive tertiary clones were amplified directly from plaques using primers against adjacent Bluescript T3/T7 promoter sites. A typical PCR would include $5 \mu \mathrm{l}$ of phage DNA dilution, $6 \mu \mathrm{l}$ of PCR mix $(0.833 \mathrm{mM}$ each dNTP, $4.17 \mathrm{mM}$ Tris-HCl, $41.67 \mathrm{mM} \mathrm{NaCl}, 2.08 \mathrm{mM}$ $\mathrm{MgCl}_{2}$ and $0.417 \mathrm{mM}$ 2-mercaptoethanol), $100 \mathrm{ng}$ of each primer and 1 unit Taq DNA polymerase (Boehringer Mannheim, Corp., Indianapolis, IN) in a total volume of $25 \mu \mathrm{l}$. PCR conditions consisted of denaturation at $94^{\circ} \mathrm{C}, 5^{\prime}$, followed by 35 cycles of $94^{\circ} \mathrm{C}, 1 \mathrm{~min}, 30 \mathrm{~s} ; 60^{\circ} \mathrm{C}, 1 \mathrm{~min}$; $72^{\circ} \mathrm{C}, 1 \mathrm{~min}$ and extension at $72^{\circ} \mathrm{C}, 7 \mathrm{~min}$. The amplified products were then cloned into the pCRII vector using the TA cloning kit (Invitrogen Co.). Colonies positive for inserts were identified using PCR. Sequence analysis of the clones was performed as previously described (Ligon et al, 1997).

\section{Northern analysis}

mRNA $(10 \mu \mathrm{g})$ from various cell lines was electrophoresed on a $0.8 \%$ denaturing formaldehyde gel (Sambrook et al, 1989). The RNA was transferred to Hybond $\mathrm{N}^{+}$membrane (Amersham Corp.) by capillary action using $10 \times$ SSC. The membrane was then baked in a vacuum oven at $80^{\circ} \mathrm{C}$ for $1-2 \mathrm{~h}$ or crosslinked using a UV crosslinker. Prehybridization was performed from $6 \mathrm{~h}$ to overnight at $65^{\circ} \mathrm{C}$ in $6 \times$ SSPE, $0.1 \%$ SDS, $10 \times$ Denhardt's solution and $100 \mu \mathrm{g} / \mathrm{ml}$ sonicated salmon sperm DNA. Radioactive double-stranded probes were prepared by random priming (Feinberg and Vogelstein, 1984). Hybridization was performed in the same solution at $65^{\circ} \mathrm{C}$ overnight. Washing conditions consisted of $2 \times$ SSPE, $0.5 \%$ SDS, $10 \mathrm{~min}$ at room temperature followed by $1 \times \mathrm{SSPE}, 0.5 \% \mathrm{SDS}$ at $65^{\circ} \mathrm{C}, 15 \mathrm{~min}$ and, if needed, $0.2 \times \mathrm{SSPE}, 0.1 \%$ SDS at $65^{\circ} \mathrm{C}$ for $15 \mathrm{~min}$. The moist membrane was heat-sealed in a 
plastic bag then exposed to Kodak XAR film with intensifying screens at $-80^{\circ} \mathrm{C}$.

\section{Acknowledgements}

This work was supported in part by National Cancer Institute grants R01 56041, R01 51148,

\section{References}

Altschul SF, Gish W, Miller W, Myers EW, Lipman DJ (1990). Basic local alignment search tool. J Mol Biology 215: $403-410$.

Aviv H, Leder P (1972). Purification of biologically active globin messenger RNA by chromatography on oligothymidilic acid-cellulose. Proc Natl Acad Sci USA 69: $1408-1412$.

Bigner SH, Mark H, Burger PC, Mahaley MS, Bullar DE, Mughlbaier LH, Bigner DD (1988). Specific chromosomal abnormalities in malignant human gliomas. Cancer Res 88: 405-411.

Bigner SH, Mark J, Bigner DD (1990). Cytogenetics of human brain tumors. Cancer Genet Cytogenet 47: $141-154$.

Chirgwin JJ, Przbyla AE, MacDonald RJ, Rutter WJ (1979). Isolation of biologically active ribonucleic acid from sources enriched in ribonuclease. Biochemstry 18: $52-94$.

Connor JR, Boeshore KL, Benkovic SA, Menzies SL (1994). Isoforms of ferritin have a specific cellular distribution in the brain. I Neurosci Res 37: 461-465.

Davis MM (1986). Subtractive cDNA hybridization and the T-cell receptor genes. In: Handbook of Experimental Immunology, DM Weir, LA Herzenberg, C Blackwell, LA Herzenberg (eds.), Vol.2, pp.76.176.13.

El-Deiry WS, Tokino T, Velculescu VE, Levy DB, Parsons R, Trent JM, Lin D, Mercer WE, Kinzler KW, Vogelstein B (1993). WAF1, A potential mediator of p53 tumor suppression. Cell 75: 817-825.

Feinberg A, Vogelstein B (1984). A technique for radiolabelling DNA restriction endonuclease fragments to high specific activity. Anal Biochem 132: 6-13.

Fults D, Pedone CA (1992). Deletion mapping of the long arm of chromosomes 10 in glioblastoma multiforme. Genes Chromom Cancer 7: 173-177.

Fults D, Pedone CA, Thomas GA, White R (1990). Allelotype of human malignant astrocytoma. Cancer Res 50: 5784-5789.

Fults D, Petronio J, Noblett BD, Pedone CA (1992). Chromosome 11p15 deletions in human malignant astrocytomas and primitive neuroectodermal tumors. Genomics 14: 799-801.

Fults D, Tippets RH, Thomas GA, Nakamura Y, White R (1989). Loos of heterozygosity for loci on chromosome $17 \mathrm{p}$ in human malignant astrocytomas. Cancer Res 49: $6572-6577$.

Hsu SC, Volpert OV, Steck PA, Mikkelsen T, Polverini PJ, Rao S, Chou P, Bouck NP (1996). Inhibition of angiogenesis in human glioblastomas by chromosome 10 induction of thrombospondin-1. Cancer Res 56: $5684-5691$.
Cancer Center Core Grant CA16672 and a grant from the Gilland Foundation. Alanosine was a generous gift from the Drug Synthesis and Chemistry Branch, Division of Cancer Treatment, National Cancer Institute. Genbank accession number for the clones are: 7-1, AF34209; 14-1, AF34207; 5-6, AF34208.

James CD, He J, Carlbom E, Nordenskjold M, Cavenee WK, Collins VP (1991). Chromosomes 9 deletion mapping reveals interferon $\alpha$ and interferon $\beta$-1 gene deletions in human glial tumors. Cancer Res 51: 1684-1688.

James D, Carlbom E, Dumanski J, Hansen M, Nordenskjold M, Collins VP, Cavanee W (1988). Clonal genomic alterations in glioma malignancy stages. Cancer Res 48: $5546-5551$.

Khan AS, Wilcox AS, Polymeropoulos MH, Hopkins JA, Stevens TJ, Robinson M, Orpana AK, Sikela JM (1992). Single pass sequencing and physical and genetic mapping of human brain cDNAs. Nature Genetics 2: $180-185$.

Li J, Yen C, Liaw D, Podsypanina K, Bose S, Wang SI, Puc J, Miliaresis C, Rodgers L, McCombie R, Bigner SH, Giovanella BC, Ittmann M, Tycko B, Hibhoosh H, Wigler MH, Parsons R (1997). PTEN, a putative protein tyrosine phosphatase gene mutated in human brain, breast, and prostate cancer. Science 275: $1943-$ 1947.

Ligon AH, Pershouse MA, Jasser SA, Yung WKA, Steck PA (1997). Identification of a novel gene product, RIG, that is down-regulated in human glioblastoma. Oncogene 14: $1075-1081$.

Mollenhauer J, Wiemann S, Scheurlen W, Korn B, Hayashi Y, Wilgenbus KK, von Deimling A, Poutska A (1997). DMBT1, a new member of the SRCR superfamily, on chromosome 10q25.3-26.1 is deleted in malignant brain tumours. Nature Genetics 17: $32-$ 39.

Myers MP, Stolarov JP, Eng C, Li J, Wagner I, Wigler MH, Parsons R, Tonks NK (1997). P-TEN, the tumor suppressor from human chromosome 10q23, is a dual-specificity phosphatase. Proc Natl Acad Sci USA 94: $9052-9057$.

Nister M, Hammacher A, Mellstrom K, Siegbahn A, Ronnstrand L, Westermark B, Heldin C-H (1988). A glioma-derived PDGF A chain homodimer has different functional activities from a PDGF AB heterodimer purified from human platelets. Cell 52: 791-799.

Pang JCS, Du RP, Bingham H, Juranka P, Chan V-L (1989). Imbalance of purine nucleotides in alanosineresistant baby hamster kidney cells. Somatic Cell Mol Genet 15: 101-111.

Pershouse MA, Stubblefield E, Hadi A, Killary AM, Yung WKA, Steck PA (1993). Analysis of the functional role of chromosome 10 loss in human glioblastomas. Cancer Res 53: 5043-5050. 
Pringle N, Collarini EJ, Mosely MJ, Heldin C-H, Westermark B, Richardson WD (1989). PDGF A chain homodimers drive proliferation of bipotential (O-2A) glial progenitor cell in the developing rat optic nerve. EMBO J 8: 1049-1056.

Raff MC, Miller RH, Noble M (1983). A glial progenitor cell that develops in vitro into an astroctye or an oligodendrocyte depending on culture medium. Nature (Lond) 274: 813-816.

Ransom DT, Ritland SR, Kimmel DW, Moertel CA, Dahl RJ, Scheithauer BW, Kelly PJ, Jenkins RB (1992). Cytogenetic and loss of heterozygosity studies in ependymomas, pilocytic astrocytomas, and oligodendrogliomas Genes Chromosom Cancer 5: 348-356.

Rasheed BKA, Fuller GN, Friedman AH, Bigner DD, Bigner SH (1992). Loss of heterozygosity for 10q loci in human gliomas. Genes Chromom Cancer 5: 75-82.

Rasheed BKA, McLendon RE, Friedman HS, Friedman AH, Fuchs HE, Biger DD, Bigner SH (1995). Chromosome 10 deletion mapping in human gliomas: a common deletion region in 10q25. Oncogene 12: 2244-2247.

Ritland SR, Ganju V, Jenkins RB (1995). Region-specific loss of heterozygosity on chromosome 19 is related to the morphologic type of human glioma. Genes Chromosom Cancer 12: 277-282.

Sambrook J, Fritsch EF, Maniatis T (1989). In Molecular Cloning: A Laboratory Manual. Second Edition, Cold Spring Harbor Laboratory Press.

Sharp MGF, Admas SM, Walker RA, Brammar WJ, Varley JM (1992). Differential expression of the mitochondrial gene cytochrome oxidase II in benign and malignant breast tissue. J Pathology 168: 163168.

Steck PA, Ligon AH, Cheong P, Yung WKA, Pershouse MA (1995). Two tumor suppressive loci on chromosome 10 involved in human glioblastomas. Genes Chromsom Cancer 12: 255-261.
Steck PA, Pershouse MA, Jasser SA, Yung WKA, Lin H, Ligon AH, Langford LA, Baumgard ML, Hattier T, Davis T, Fyre C, Hu R, Swedlund B, Teng DHF, Tavtigian S (1997). Identification of a candidate tumor suppressor gene, MMAC1, at chromosome 10q23.3 that is mutated in multiple advanced cancers. Nature Genetics 15: $356-362$.

Stehelin D, Guntaka RV, Varmus HE, Bishop JM (1976). Purification of DNA complementary to nucleotide sequences required for neoplastic transformation of fibroblasts by avian sarcoma viruses. J Mol Biol 101: $349-365$.

Stubblefield E, Pershouse M (1992). Direct formation of microcells from mitotic cells for use in chromosome transfer. Somatic Cell Mol Genet 18: 485-491.

Vayssiere J-C, Cordeau-Lossouarn L, Larcher JC, Basseville M, Gros F, Croizal B (1994). Participation of the mitochondrial genome in the differentiation of neuroblastoma cells. In Vitro Cell Dev Biol 28A: 763-772.

von Deimling A, Louis DN, von Ammon K, Petersen I, Hoell T, Chung RY, Martuza RL, Schoenfeld DA, Yasrgil MG, Wiestler OD (1992). Association of epidermal growth factor receptor gene amplification with loss of chromosome 10 in human glioblastoma multiforme. J Neurosurg 77: 295-301.

Williams KA, Deber CM (1993). The structure and function of central nervous system myelin. Crit Rev Clin Lab Sci 30: 29-64.

Wong AJ, Bigner SH, Bigner DD, Kinzler KW, Hamilton SR, Vogelstein B (1987). Increased expression of the EGF receptor gene in malignant gliomas is invariably associated with gene amplification. Proc Natl Acad SCi USA 84: 6899-6903.

Yung WKA, Lotan R, Lee P, Lotan D, Steck PA (1989). Modulation of growth and epidermal growth factor receptor activity by retinoic acid in human glioma cells. Cancer Res 49: 1014-1019. 